\title{
International Trade, Financial Development, Foreign Exchange Reserve and Output in Indonesia
}

\author{
Muhammad Nur Syamsi ${ }^{1}$, Rossanto Dwi Handoyo ${ }^{2}$, \\ Abdul Rahim Ridzuan ${ }^{3}$, Mohamad Idham Md Razak ${ }^{4}$ \\ E-mail: matnawihafizah@gmail.com
}

\begin{abstract}
The purpose of this paper is to analyze the relationship between international trade, financial development, Foreign Exchange reserve and Output of Indonesia. This paper used quarterly time series data from quarter 1, 2000 until quarter 3, 2016. This study used Structural Vector Auto Regression (SVAR). The result found that output was positively affected by money supply and export, and negatively affected by domestic credit of bank, domestic credit to private sector, and import.

Key words

Foreign Exchange Reserve, International Trade, Financial Development, Output, SVAR.

Received: 03 Apr $2020 \quad$ C The Authors 2020

Revised: 27 Apr $2020 \quad$ Published by Human Resource Management Academic Research Society (www.hrmars.com)

Accepted: 16 May 2020 This article is published under the Creative Commons Attribution (CC BY 4.0) license. Anyone may Published Online: $\quad 30$ May 2020 reproduce, distribute, translate and create derivative works of this article (for both commercial and non-commercial purposes), subject to full attribution to the original publication and authors. The full terms of this license may be seen at: http://creativecommons.org/licences/by/4.0/legalcode
\end{abstract}

\section{Introduction}

Indonesia is a developing country with great economic potential and has gained sizeable attention from the international community. Indonesia possesses numerous characteristics to rapidly help its economic progression, as seen in its economic growth. Gross domestic product (GDP) is an important factor in evaluating economic performance (Gokmenoglu et al., 2015). Also, GDP has the aim of summarizing economic activity in currency and a certain period (Mankiw, 2006). Proper and effective management of resources and the increased support of renewable technology create sustainable economic activities.

The output is the ultimate goal of economic activity to supply goods and services to society (Samuelson \& Nordhaus, 2004). When output production is steady, economic activity will take place continuously and eventually; output production would become larger that would lead to an increase of GDP, which is a benchmark of economic growth. The development of GDP in Indonesia in the period 20002016 showed an increasing trend. 2016 was the peak acquisition of Indonesia's real GDP, which amounted to 9,433 trillion rupiahs.

Every country has different characteristics of natural resources. The difference in wealth can be either raw natural products or processed products. Besides, the human resources owned by each country can be different. Countries that have few natural resources would try to improve the human resources they have. The superiority of human resources would yield better capability of making high-value production goods. Countries that cannot produce a particular item would resort to importing the item.

Provision of domestic needs is an essential factor in the welfare of a country. When a developing country can conduct international trade, it can create jobs and supply goods that cannot be produced 
locally (Salvatore, 2014). Free trade creates relations between countries and has the nature of interdependence.

Shahbaz \& Rahman (2014) stated that exports could cause an increase in GDP. The first phase starts with output growth, and then, it becomes export growth. Through trade activities, companies can get innovations in technology, capacity building for workers, and technology transfer. Increased domestic production will trigger sales in the global market. Ductor \& Grechyna (2015) explained that financial development is an essential factor that determines the level of GDP. Financial development has an evident influence on the level of GDP. A good financial system provides facilities for deposit mobilization and guarantees efficient resource allocation (King \& Levine, 1993). A good economy is undoubtedly supported by a good financial system. Proper financial allocation is useful to improve production performance.

Kumarasinghe (2016) stated that financial development would optimize the production activities of local companies. Financial development provides an access to local and international capital markets. Financial developments can invite foreign investment in developing countries. The presence of foreign investment can increase the integration between local financial markets and world financial markets. This is why export-based countries must improve their performance in the international market. Haija (2017) explained that the financial sector could channel capital resources to potential companies and industries. If the financial sector were developed, it would increase the ability to allocate capital resources to productive investments. Besides, capital injections will encourage companies to be more active in operating and simultaneously, increasing income that stimulates an increase in GDP. Capital allocation by the banking sector will encourage the growth of local industries from small to large scale. Maintaining this industry would benefit from increasing the scale of production at both domestic and international levels. A form of allocation is a loan provided by banks to companies. The allocation of loans would be able to encourage export production. The result of an increase in exports will be a factor in increasing GDP.

\section{Literature review}

According to Mankiw (2006), GDP is the overall value of all goods and services produced in the economy during a certain period. There are two ways to determine the amount of GDP, either to see the total income of an economy or to see the amount of expenditure from the production of goods and services. According to Mankiw (2006), there are two types of GDP, namely real GDP and nominal GDP. Samuelson and Nordhaus (2004) stated that increasing GDP is a strengthening of national output. This is related to the growth of per capita output which is a picture of life welfare. Good living welfare would increase income. There are four factors for increasing GDP, namely human resources, natural resources, capital formation, and innovation technology.

Trade is carried out based on trust and mutual benefit. Trade causes each individual to specialize, the existence of international trade causes countries to specialize in the production and enjoy more goods and services (Mankiw, 2009). International trade is an economic activity that exchanges goods and services between countries (Syafril, 2005). International trade between countries is based on export and import performance. Traffickers can be individuals, groups, private business entities or government business entities.

According to Adam Smith in the theory of absolute excellence, international trade occurs if each country has an absolute advantage. A country will export goods that have absolute advantages over other countries, but import goods that have total losses over other countries. This method will encourage efficient use of resources, then increase the yield of the types of goods that have the advantages of specialization results (Salvatore, 2014).

Meanwhile, David Ricardo perfected the theory of absolute excellence in the theory of comparative advantage. Ricardo explained that even though a country has fewer goods than other countries, the country can still benefit from trade. Countries that have comparative advantages can still export and import goods that have comparative weaknesses (Syafril, 2005).

Later, Eli Heckscher and Bertil Ohlin offer a theory on international trade based on differences in the abundance of natural factors (endowment factors) between countries. A country will export goods that have an abundance of inputs in their countries and will import goods that have a scarcity of input in their countries. 
Finance is an essential factor in the economy. Improving financial development will lead to a better economic process. Finance can be an input to achieve a decent level of income and quality of life. However, financial factors are not enough to achieve a level of economic success.

Rapid economic development will drive the progress of the financial sector. This is reflected in the condition of the financial sector that increasingly established in guaranteeing a country's finances. The financial sector is an integral part of supporting the economic process. Along with the times, the financial sector experienced changes that could affect production activities. The implementation is by providing loans for both production and investment (Yustika \& Sulistiani, 2007).

There are various variables related to financial development, and these variables are indicators of financial development in a country. According to Mukhlis (2011), financial development is measured through credit proxies and $M 2$, namely the money supply in a broad sense. Credit and $M 2$ can be a benchmark for measuring financial development

Credit distribution aims to increase the value of bank wealth and the level of the economy (Ningsih \& Zuhro, 2010). In essence, banks will always try to avoid bad credit, and the bank needs to continuously develops its strength in credit to mobilize sustainable credit capacity and the same time, carry out its function as financial intermediation.

Credit allocation is vital for the business world. The relationship cannot be severed, as the bank will always channel credit in the form of investment credit and working capital needed in business. According to Hassan (2011), domestic credit from banks consists of loans distributed to all sectors, without regard to credit for the central government. Domestic credit for the private sector is the distribution of finance for the needs of the private sector through loans, trade credit and others. The provision of credit aims to facilitate the private sector in terms of increasing production.

Samuelson \& Nordhaus (2004) state that money is something that functions as a generally accepted medium of exchange. The most crucial concept is money in a narrow sense (M1), consists of currency and demand deposits circulating in the community. Another important indicator is money in broad terms (M2), namely M1 plus quasi money.

King \& Levine (1993) state that if there is a relationship between financial development as a financial intermediary, namely channeling credit to the private sector. Financial intermediaries can provide benefits such as determining risk diversification and facilitating the distribution of funding sources. Developing financial system will increase capital formation and efficiency in allocating financial resources so that in the end, it will support the increase in GDP. Domestic credit for the private sector can be in the form of loans, purchase of non-equity securities, trade credit and other receivables. The financial sector that provides credit covers all financial sectors, such as monetary authorities, banks, and other financial companies.

According to McEachern (2000), demand for money is the amount of money that a person wants to hold. According to the quantity theory of money, there is a relationship between changes in the money supply and the price level. Broad money is defined as money that covers all elements of finance, such as M1 added with time deposits, savings deposits, and non-stock securities (Mankiw, 2006).

Domestic credit by banks is credit that is only channeled by banking banks. Credit is given to all sectors, except credit for the central government. According to Ductor \& Grechyna (2015), the right increase in domestic credit by banks will reduce transaction costs, mobilize savings, and facilitate the efficient allocation of funding sources.

\section{Methodology of research}

The method used in this study is SVAR, a useful method for analyzing how a variable responds to changes in other variables, by giving a restriction to separate movement. This study uses data spanning in 16 years starting from 2000: Q1 until 2016: Q3. The data in this study is secondary data, presented in the form of time series, covering the period between 2000: Q1 up to 2016: Q3. This secondary data was obtained from the Central Statistics Agency and the Bank Indonesia website.

This research uses the SVAR (Structural Vector Auto Regression) economic analysis method. SVAR is developed from the VAR method using some restrictions in the model. The restriction is applied to the matrix component based on a robust theoretical relationship between variables in the VAR system. 
Therefore, the form of SVAR is often referred to as a theoretical VAR. SVAR estimation models in matrix form can be written as follows:

$\left[\begin{array}{c}e_{\mathrm{M} 2 \mathrm{t}} \\ e_{\mathrm{DCBt}} \\ e_{\mathrm{DCPSt}} \\ e_{\mathrm{Imt}} \\ e_{\mathrm{Ext}} \\ e_{\mathrm{GDPt}}\end{array}\right]=\left[\begin{array}{cccccc}a_{11} & 0 & 0 & 0 & 0 & 0 \\ a_{21} & a_{22} & 0 & 0 & 0 & 0 \\ a_{31} & a_{32} & a_{33} & 0 & 0 & 0 \\ a_{41} & a_{42} & a_{44} & a_{44} & 0 & 0 \\ a_{51} & a_{52} & a_{53} & a_{54} & a_{55} & 0 \\ a_{61} & a_{62} & a_{63} & a_{64} & a_{65} & a_{66}\end{array}\right]\left[\begin{array}{c}\varepsilon_{\mathrm{M} 2 \mathrm{t}} \\ \varepsilon_{\mathrm{DCBt}} \\ \varepsilon_{\mathrm{DCPSt}} \\ \varepsilon_{\mathrm{Imt}} \\ \varepsilon_{\mathrm{Ext}} \\ \varepsilon_{\mathrm{GDPt}}\end{array}\right]$

In which:

M2: money supply; DCB: domestic credit by banks; DCPS: domestic credit to private sector

Im: import; Ex: export; GDP: gross domestic product; $e_{\mathrm{t}}$ : endogen variable vector;

$a_{\text {contemporaneous relations among variables; }} \varepsilon_{\mathrm{t}}$ : error term of orthogonal shocks.

\section{Results and Discussions}

\subsection{Stationary Test}

The Phillips-Perron stationary test (PP) was carried out at level. Stationary variables were obtained from the ADFt-statistical value, and these variables have the greater MacKinnon value of the critical value, valued at both at $1 \%, 5 \%$, or $10 \%$ error rates. The test results showed that all variables are not stationary at the level of the intercept level. Thus, the stationary test was carried out at the first difference level, and the results were obtained, as shown in the table below.

Table 1. PP Test Results: First Difference-Trend and Intercept

\begin{tabular}{|c|c|c|c|c|c|c|}
\hline \multirow{2}{*}{ Variable } & \multirow{2}{*}{ t-stat } & \multicolumn{3}{|c|}{ t-statistic } & \multirow{2}{*}{ p-value } & \multirow{2}{*}{ Informatior } \\
\hline & & $1 \%$ & $5 \%$ & $10 \%$ & & \\
\hline GDP riil & -9.70071 & -4.10553 & -3.48046 & -3.16804 & 0 & Stationary \\
\hline Exports & -6.44529 & -4.10553 & -3.48046 & -3.16804 & 0 & Stationary \\
\hline Imports & -5.64376 & -4.10553 & -3.48046 & -3.16804 & 0.0001 & Stationary \\
\hline DCPS & -7.49458 & -4.10553 & -3.48046 & -3.16804 & 0 & Stationary \\
\hline DCB & -7.69278 & -4.10553 & -3.48046 & -3.16804 & 0 & Stationary \\
\hline $\mathrm{M} 2$ & -7.28314 & -4.10553 & -3.48046 & -3.16804 & 0 & Stationary \\
\hline
\end{tabular}

Notes: *significant at $\alpha=10 \%,{ }^{* *}$ significant at $\alpha=5 \%,{ }^{* * *}$ signifikan $\alpha=1 \%$

\subsection{Determining Lag Length Optimal}

After the variables in stationary studies were known at the first-difference level, the lag length was determined by several criteria such as Likelihood Ration (LR), Final Prediction Error (FPE), Akaike Information Criterion (AIC), Schwarz Information Criterion (SC), and Hannan-Quinn Criterion (HQ). In timeseries data, testing is susceptible to the existence of optimal lag. Determining optimal lag was conducted to determine the adequacy of the data and the period used during the study. To get optimal lag, the following results were obtained:

Table 2. Lag Optimal Test Results

\begin{tabular}{ccccccc}
\hline Lag & LogL & LR & FPE & AIC & SC & HQ \\
\hline 0 & -1621.199 & NA & $5.96 \mathrm{E}+15$ & 53.3508 & $53.55842^{*}$ & 53.43217 \\
1 & -1568.26 & 93.72942 & $3.44 \mathrm{E}+15$ & 52.7954 & 54.24878 & $53.36499^{*}$ \\
2 & -1536.658 & $4.97 \mathrm{E}+01$ & $4.11 \mathrm{E}+15$ & 52.93962 & 55.63877 & 53.99744 \\
3 & -1498.552 & 52.47426 & $4.19 \mathrm{E}+15$ & 52.87056 & 56.81547 & 54.41661 \\
4 & -1426.873 & $84.60438^{*}$ & $1.56 \mathrm{E}+15^{*}$ & 51.70077 & 56.89144 & 53.73504 \\
5 & -1382.302 & 43.84032 & $1.61 \mathrm{E}+15$ & $51.41975^{*}$ & 57.85618 & 53.94225 \\
\hline
\end{tabular}

Source: Eviews 8, processed by the author. 
Based on the results of determining the optimal lag above, the results of testing GDP, exports, imports, domestic credit to the private sector, domestic credit by banks, and M2 Indonesia obtained a variety of optimal lags. Based on the SC criteria is at zero lag, the HQ criteria were produced at one lag, then the FPE and LR criteria were produced in the four lags, and lastly, the AIC criteria was produced at five lags. Based on the highest number of $(*)$ signs, it can be concluded that this study used an optimal lag of four SVAR Estimation Results. SVAR is a theoretical and non-recursive model and enforces several restrictions in its method. The estimation results show that if exports, imports, domestic credit to the private sector, domestic credit by banks, and M2 are statistically significant, they will affect GDP in Indonesia. The estimation results can be seen from the probability value compared to the $5 \%$ significance level as below:

Table 3. SVAR Estimation Results

\begin{tabular}{clcccc}
\hline & \multicolumn{1}{c}{ Variable } & Coefficient & Std. Error & z-statistic & Prob. \\
\hline C (6) & M2 & 46.21285 & 4.20443 & 10.99145 & 0 \\
C (11) & Domestic Credit by Banks & -1.72985 & 0.656 & -2.63696 & 0.012 \\
& Domestic Credit to Private & & & & \\
C (15) & Sector & -2.43888 & 0.59853 & -4.0748 & 0 \\
C (18) & Imports & -1.17867 & 0.54687 & -2.15531 & 0.031 \\
C (20) & Exports & 1.90133 & 0.50863 & 3.73814 & 0 \\
\hline
\end{tabular}

Source: Eviews 8, table is processed by the author.

Estimation results were obtained if each variable has a different coefficient value. Probability values that are smaller than the significance level of $1 \%$ and $5 \%$ indicate that all variables are a statistically significant influence on Indonesia's GDP. Identification of each variable in this study is:

1. The regression coefficient in the M2 variable is 46.21285 with a significance level of $1 \%$. This means that the M2 variable has a positive and significant effect on GDP in Indonesia. When M2 increased to1 trillion, Indonesia's GDP would increase by 46.21285 trillion, assuming the other variables are constant.

2. The regression coefficient on domestic credit by banks variable is valued at -1.72985 , at a significance level of $5 \%$. This means that the domestic credit by banks variable has a negative and significant effect on GDP in Indonesia. If domestic credit by banks increased by 1 trillion, Indonesia's GDP would decrease by 1.72985 trillion, assuming other variables is constant.

3. The regression coefficient on the domestic credit to private sector variable is valued at -2.43888 , at a significance level of $1 \%$. This means that the domestic credit to private sector variable has a negative and significant effect on GDP in Indonesia. If domestic credit to the private sector increased to 1 trillion, Indonesia's GDP would decrease by 2.43888 trillion, assuming other variables are constant.

4. The regression coefficient on the import variable is valued at -1.1788 , at a significance level of $5 \%$. This means that the import variable has a negative and significant effect on GDP in Indonesia. If increasing imports were made to 1 trillion, Indonesia's GDP would decrease by 1.17867 trillion, assuming other variables are constant.

5. The regression coefficient on the export variable is valued at 1.90133 , at a significance level of $1 \%$. This means that the export variable has a positive and significant effect on GDP in Indonesia. If exports were increased by 1 trillion, Indonesia's GDP would increase by 1.90133 trillion, assuming other variables are constant.

\subsection{Impulse Response Function Results}

The figure below shows the increase of $M 2$ is responded positively by GDP in the first period. The highest response was seen during the first period, based on a response of $1.5 \mathrm{SD}$, then the response tends to decrease. The response of Indonesia's GDP then shrinks and approaches the balance point or approaches zero until the end of the period. 


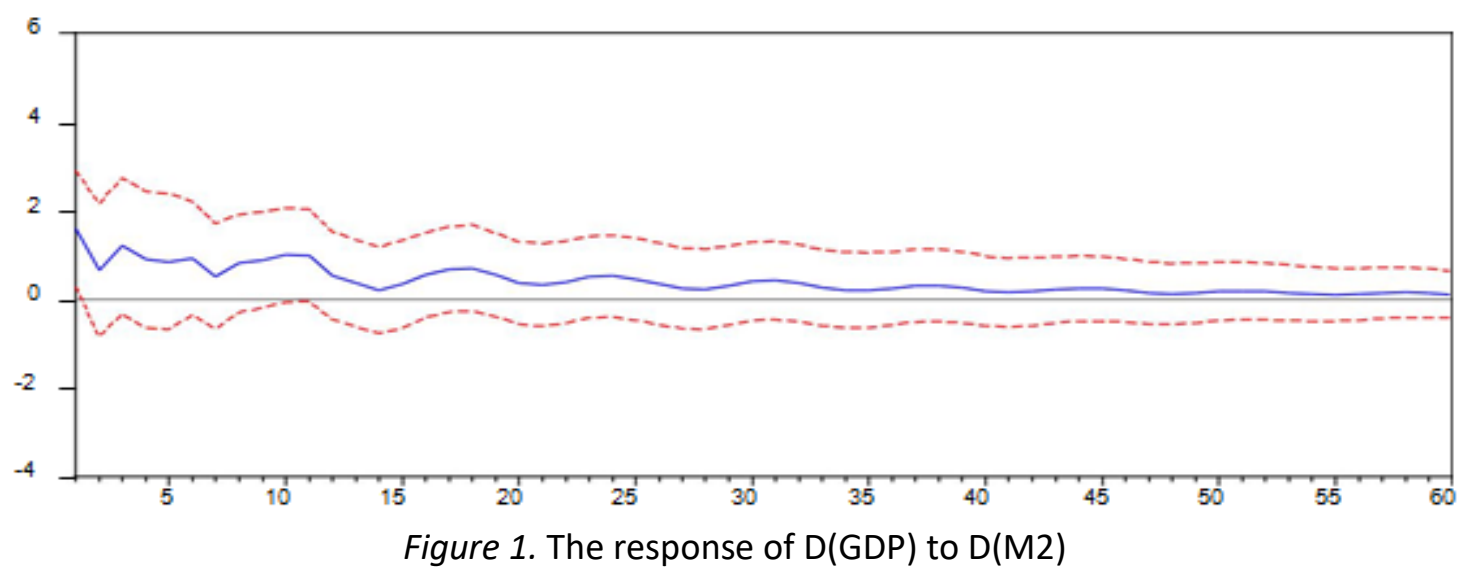

The figure below shows a fluctuating GDP response to domestic credit by banks shock, where initially, GDP responded positively to the domestic credit by banks shock. Still, the positive response only persisted in the first two periods. During the third period, GDP responded negatively to -0.16 SD and then, declined until the sixth period. The biggest decline occurred during the fifth period of $-0.60 \mathrm{SD}$. The response shown by GDP fluctuates to near the equilibrium line or zero at the end of the period.

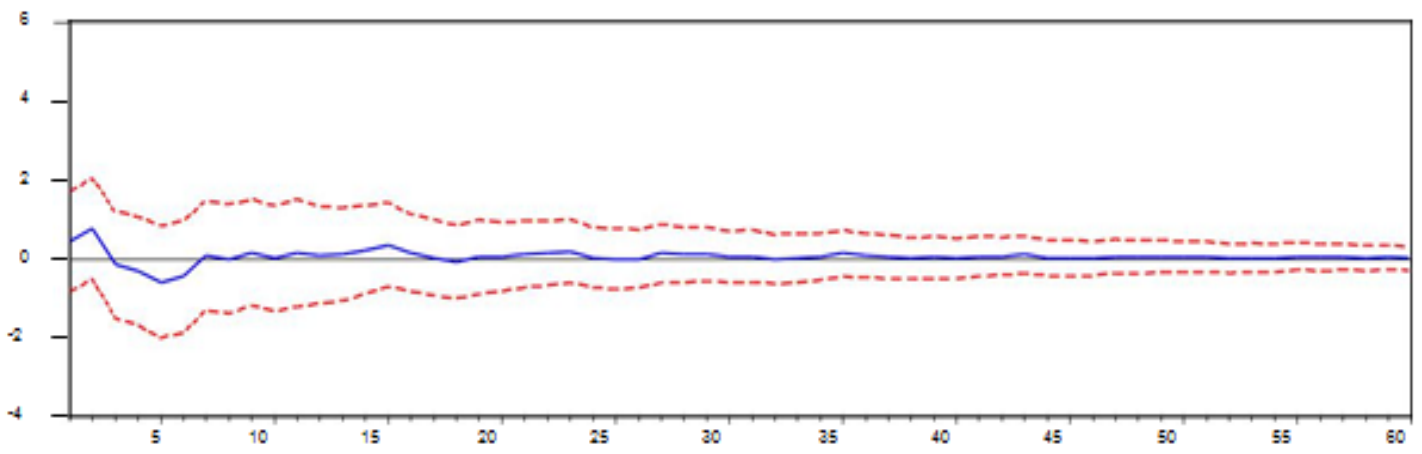

Figure 2. The response of $D(G D P)$ to $D(D C B)$

The next variable is the response of GDP to domestic credit to private sector shock. The figure below shows that GDP responds negatively to the domestic credit to private sector shock. This is in line with the results of SVAR, where SVAR test results state that domestic credit to private sector harms Indonesia's GDP. The lowest GDP response is $-1.46 \mathrm{SD}$ at the beginning of the period, and the highest is $0.23 \mathrm{SD}$, in the eighth period. In the end, the response given would approach the equilibrium point until the end of the period.

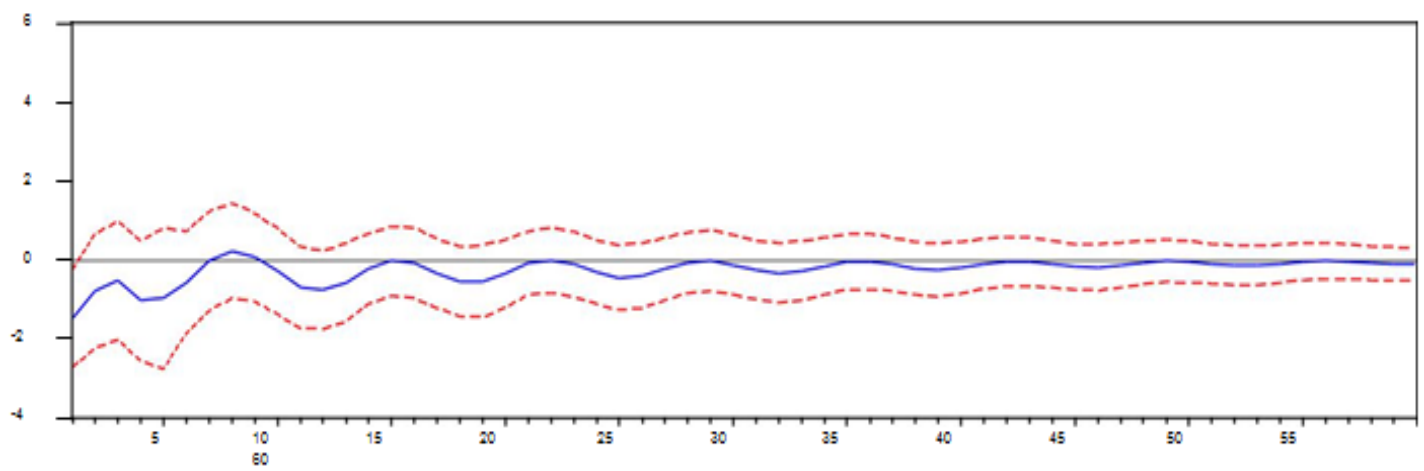

Figure 3. The response of $D(G D P)$ to $D(D C P S)$

Based on the following figure, the import shock responded positively by the GDP variable only for two initial periods, then showed a movement of responses that leaned towards negative. The highest response was shown at 1.18 SD in the second period, and the lowest was -0.70 SD, in the fourth period. The impact of shock was felt up to eleven periods, after which the impact of shock began to diminish, which was shown by a movement that was not too fluctuating, after which the impact of the shock would approach the equilibrium point until the end of the period. 


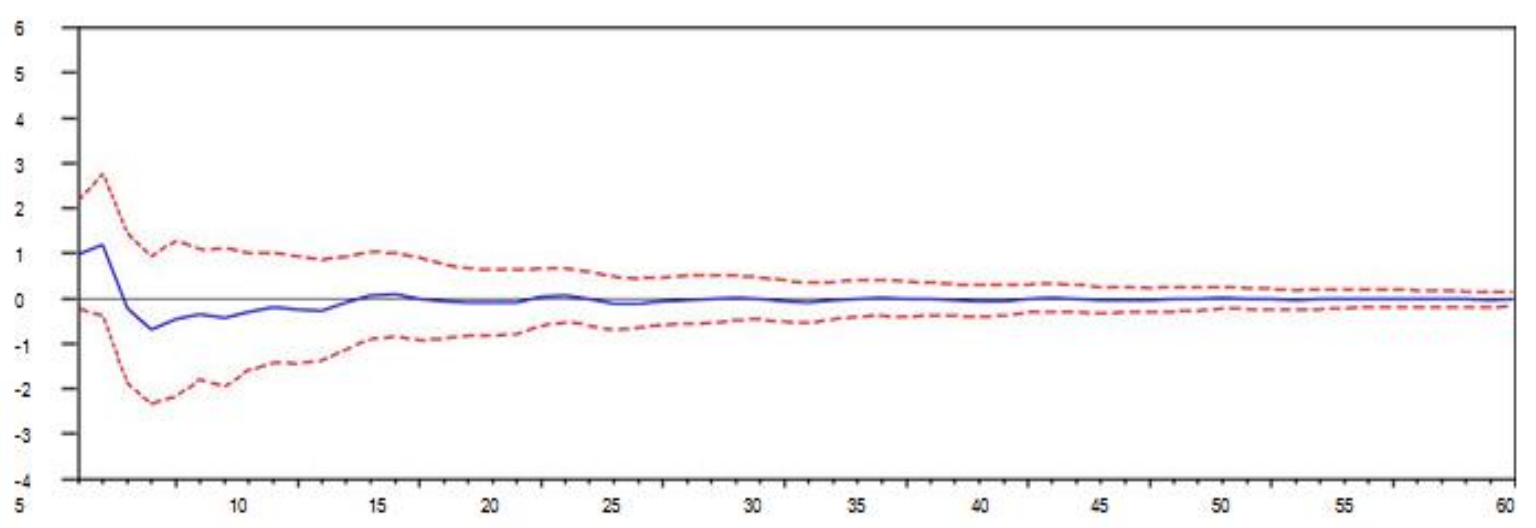

Figure 4. The response of $\mathrm{D}(\mathrm{GDP})$ to $\mathrm{D}(\mathrm{IM})$

The figure below shows the movement of the GDP variable response. The GDP response tends to fluctuate since the shock of the export variable. In the first period, the GDP variable immediately responded negatively to $-0.14 \mathrm{SD}$. Still, in the second period to the fourth period, the GDP variable responded positively to the shock of the export variable. The highest peak of the response of the GDP variable in the tenth period, a positive response was recorded at $0.71 \mathrm{SD}$. After that, the impact of the shock began to decrease and approached the point of balance until the end of the period.

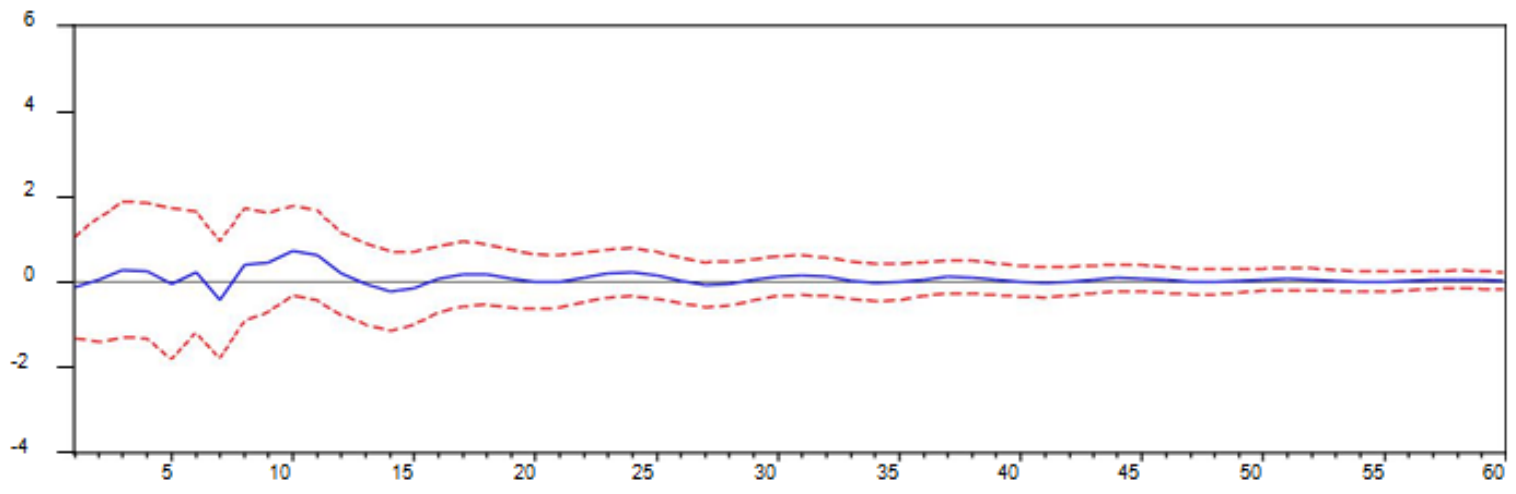

Figure 5. The response of $D(G D P)$ to $D(E X)$

\subsection{Forecast Error Variance Decomposition Results}

Variance Decomposition analysis was used to determine the contribution of the independent variable shock to changes in the level of Indonesia's GDP. This study applied the GDP variable as an endogenous (dependent) variable. Variance Decomposition analysis would identify variables that have the greatest role in explaining changes in the endogenous variables. The results of the FEVD analysis can be seen in the following table:

Table 4. Forecast Error Variance Decomposition Results

\begin{tabular}{cccccccc}
\hline Period & S.E. & D(M2) & D(DCB) & D(DCPS) & D(IM) & D(EX) & D(GDP) \\
\hline 1 & 5.27523 & 9.026716 & 0.637879 & 7.756362 & 3.434677 & 0.075713 & 79.06865 \\
6 & 6.765652 & 14.59647 & 3.156813 & 11.69759 & 7.056751 & 0.462818 & 63.02956 \\
12 & 7.596831 & 18.30438 & 2.595306 & 11.37626 & 6.383893 & 2.88787 & 58.4523 \\
18 & 7.966087 & 18.97595 & 2.681844 & 11.61338 & 5.858001 & 2.847388 & 58.02344 \\
24 & 8.188474 & 19.69008 & 2.627703 & 11.77921 & 5.59822 & 2.835616 & 57.46917 \\
30 & 8.326264 & 19.97417 & 2.591067 & 12.00315 & 5.427441 & 2.8082 & 57.19597 \\
36 & 8.416446 & 20.23391 & 2.572872 & 12.13311 & 5.330413 & 2.800792 & 56.9289 \\
42 & 8.471951 & 20.41397 & 2.549426 & 12.20655 & 5.271649 & 2.796914 & 56.76149 \\
48 & 8.507174 & 20.53477 & 2.542306 & 12.23942 & 5.234323 & 2.79649 & 56.6527 \\
54 & 8.528966 & 20.60978 & 2.536389 & 12.25262 & 5.21146 & 2.793656 & 56.59609 \\
60 & 8.542618 & 20.6529 & 2.534567 & 12.25517 & 5.196941 & 2.791426 & 56.56899 \\
\hline
\end{tabular}


The table above shows the results of testing variance decomposition. Based on the results of the test, the changes that occur in the GDP variable are affected by the variable shock itself and the shock of other variables. In the first period, GDP is affected by the variable shock itself by $79.06 \%$ and always decreases in the next period. At the end of the period, the effect of the variable shock itself is $56.56 \%$.

The second variable that gives the largest contribution is the $\mathrm{M} 2$ variable, as indicated by the largest variance decomposition percentage and always increases until the end of the period. In the first period, the M2 variable was recorded to have an influence contribution of $9.02 \%$, while the export variable had the smallest contribution of $0.07 \%$. In the 30th period, M2 variable still had a contribution of $19.97 \%$, but domestic credit by banks variable had a contribution of $2.53 \%$. At the end of the period, the domestic credit by banks variable still has the smallest contribution compared to other variables.

\section{Discussions}

Free trade is an activity of buying and selling that between countries. In its implementation, it requires an agreement among countries. International trade is carried out as an effort to meet domestic needs, while also selling excess goods and services domestically. This is conducted to improve the economy of a country, which is in line with research conducted by Gokmenoglu et al. (2015). Based on the tests that have been conducted on the effect of the variables of export and import on Indonesia's GDP, the export variable has a positive effect of 1.90. It is significant for Indonesia's GDP, while the import variable has a negative effect of -1.17 and is significant for Indonesia's GDP. Based on SVAR estimation results, export variables have a positive and significant influence on Indonesia's GDP. This indicates that any increase in exports would increase Indonesia's GDP, similar to the results of Shahbaz \& Rahman (2014). Import variables have a negative and significant influence on Indonesia's GDP. This means that any increase in imports would reduce Indonesia's GDP, similar to the statement of Zahonogo (2017), where an exportoriented country would experience positive growth, whereas if a country-oriented to imports, it would experience a low GDP increase.

Conditions in Indonesia are per Zahonogo's research (2017), the results of his research explained that exports had a positive effect, while import would negatively affecting economic growth. Developing countries must control trade efficiently, especially at the level of imports. When it can push the GDP level, trade-in developing countries should provide access to investment and production of goods for economic development. A country needs to reduce imports of consumer goods but must create conditions for producing domestic goods efficiently, which can provide a comparative advantage. Financial development can be interpreted as the development of policies, performance, and institutions in the financial sector, and all must carry out their functions efficiently. Financial development is the process of growing the financial sector to a more advanced level, whether in allocating funds effectively, maintaining the smoothness of the payment system, and reducing financial risk. In the end, it must support an increase in GDP. The results of the study show that domestic credit to the private sector and domestic credit by banks have a negative effect on increasing GDP. In contrast, the M2 variable has a positive effect on increasing GDP. Based on the estimation results, the $\mathrm{M} 2$ variable has a positive and significant effect on increasing Indonesia's GDP. This means that if the money supply increases, the GDP level would also increase. If there is excess money supply, the central bank will practice a policy of lowering the interest rate. This condition will trigger investors to invest, and it would increase the level of output and trigger an increase in GDP. This result is in line with research conducted by Gokmenoglu et al. (2015), namely the money supply can stimulate an increase in GDP.

The financial sector has a strategic position in the economy. The financial sector can channel funds to productive sectors in the economy to create an increase in GDP. Fund disbursement to productive sectors can minimize the risk of problem loans, thereby increasing production efficiency and increasing output growth. Based on the tests, it was found that if the credit variable, namely the domestic credit to private sector variable and domestic credit by banks variable, would negatively affect Indonesia's GDP. This result is in line with the results of research conducted by Ductor \& Grechyna (2015), where improper credit channels would disrupt the increase in GDP. If credit growth is not balanced with real sector growth, it would have a negative effect. This happens if the increase in credit provision is not followed by credit 
demand by the productive sector, as it would bring up several problems such as risky investments and cause low GDP levels.

\section{Conclusions}

Based on the results of testing and discussion of the influence of international trade and financial development on Indonesian GDP, the following conclusions are obtained:

1. The money supply has a positive and significant influence on economic growth. When the money supply increases, it will increase Indonesia's GDP.

2. Export variables have a positive and significant influence on Indonesia's GDP. When exports increase, it will increase Indonesia's GDP.

3. Domestic credit by banks variable has a negative and significant influence on Indonesia's GDP. When domestic credit by banks increases, it would reduce Indonesia's GDP.

4. Domestic credit to private sector variables has a negative and significant influence on Indonesia's GDP. When domestic credit to the private sector increases, it would reduce Indonesia's GDP.

5. Import variables have a negative and significant influence on Indonesia's GDP. When imports increase, it will reduce Indonesia's GDP.

6. $\mathrm{M} 2$ variable gives the biggest contribution to changes in GDP variables, which is $20.6 \%$ at the end of the period.

7. Domestic credit to private sector variables contributes to $12.2 \%$ to changes in GDP variables at the end of the period.

8. Import variables contribute $5.1 \%$ to changes in GDP variables at the end of the period.

9. Export variables contribute $2.7 \%$ to changes in GDP variables at the end of the period.

10. The domestic credit by banks variable contributes $2.5 \%$ to changes in the GDP variable at the end of the period.

11. The response generated by economic growth in the face of the shock of independent variables in the initial period, most variables have similarities with the results of SVAR testing. The GDP variable provides a fluctuating response throughout the period, but at the end of the period shows the GDP response to the shock of all variables giving the same response that is, returning to the point of balance.

\section{Policy Recommendations}

Based on the results of research on the influence of international trade and financial development on Indonesia's GDP, these suggestions are as follows:

1. The money supply has a positive influence and gives the largest contribution to changes in the GDP variable. Increasing the money supply can trigger an increase in GDP, but this must be balanced with an increase in the supply of goods and services to control inflation.

2. Export variables have a positive influence on Indonesia's GDP. The government needs to further increase Indonesia's exports, by continuing to improve the quality of the product and increasing promotion to expand global external markets, supported by export institutions.

3. Import variables negatively affect Indonesia's GDP; imports are not only aimed at consumer goods but also in capital goods to encourage growth. Besides, the country can carry out substitution strategies that can meet domestic needs for imported goods. This can stimulate economic activities of domestic entrepreneurs.

4. Credit variables have a negative influence on economic growth. The level of credit growth must be balanced with the rate of real output growth, and lending must meet the criteria of eligibility in credit to avoid creating bad credit, as it would stimulate an increase in GDP.

\section{References}

1. Alege, P. O., and Okodua, H. (2014). International Competitiveness and Growth of the Nigerian Economy: A Structural VAR-Based Perspective. Research in Applied Economics, 6(4).

2. Amisano, G., Giannini, C. (1997). Topics in Structural VAR Econometrics. Berlin: Springer-Verlag.

3. Appleyard, D. R., and Field, A. J. (2014). International Economics. New York: McGraw-Hill. 
4. Badan, P. St. (2017). Statistic Indonesia. (online). (https://www.bps.go.id, diakses tangga 25 Februari 2017.)

5. Bank Indonesia. (2017). Perkembangan uang Beredar. (online) (http://www.bi.go.id/id/publikasi/ perkembangan/Default.aspx), diakses tanggal 25 Februari 2017)

6. Ductor, L., and Grechyna, D. (2015). Financial development, real sector, and economic growth. International Review of Economics and Finance.

7. Enders, W. (2015). Applied Econometric Time Series. New Jersey: John Wiley \& Sons, Inc. Gokmenoglu, Korhan K, et al. 2015. The Relationship among International Trade, Financial Development and Economic Growth: The Case of Pakistan. Procedia Economics and Finance 25, 489 - 496.

8. Haija, H. Z., Teheni, El. G. E. Abu Al. (2017). Financial Development, Islamic Finance and Economic Growth: Evidence from the UAE. Journal of Islamic Accounting and Business Research, Vol. 8 Iss 1.

9. Khan, M. T. I. (2014). Trade openness and economic growth in the Asian region. Journal of Chinese Economic and Foreign Trade Studies, 7(3): 136-152.

10.King, R. G., and Levine, R. (1993). Finance, entrepreneurship, and growth Theory and evidence. Journal of Monetary Economics 32, 513-542.

11.Krugman, P. R., and Obstfeld, M. (2009). International Economics: Theory \& Policy. Boston: Pearson Addison Wesley.

12.Kumarasinghe, C. V. S. (2016). Financial Development, International Trade Integration and Stock Market Integration: Evidence from Asia. Journal of Multinational Financial Management.

13.Lam, R. C. (2013). Export and growth: a linkage effect perspective. International Journal of Development Issues, 12(1): 53-66.

14.Mankiw, N. G. (2006). Makroekonomi. Jakarta: Erlangga.

15.Mankiw, N. G. (2009). Pengantar Ekonomi Mikro. Jakarta: Salemba Empat.

16.McEachern. (2000). Ekonomi Makro. Jakarta: Salemba Empat.

17.Mishkin, F. S., and Eakins, S. G. (2003). Financial market and institutions. New York: Pearson Prentice Hall.

18.Mukhlis, I. (2011). Kausalitas Dinamis antara Financial Development, Liberalisasi Perdagangan dan Pertumbuhan Ekonomi di Indonesia dalam Menyongsong Pemberlakuan Asean Economic Community. Ekonomi Pembangunan Fakultas Ekonomi Universitas Negeri Malang.

19.Ningsih, D. I. Z. (2010). Analisis Permintaan Kredit Investasi Pada Bank Swasta Nasional di Jawa Timur. Jurnal Ekonomi Pembangunan, 8(2).

20.Prasetyo, P. E. (2009). Fundamental Makro Ekonomi. Yogyakarta: Beta Offset.

21.Salvatore, D. (2014). Ekonomi Internasional. Jakarta: salemba empat.

22.Samuelson, P. A., and Nordhaus, W. D. (2004). Ilmu Makroekonomi. Jakarta: P.T. Media Global Edukasi.

23.Seidman, K. F. (2005). Economic development finance. California: Sage Publication, Inc. Shahbaz.

24.Muhammad and Rahman, M. M. (2014). Exports, financial development and economic growth in Pakistan. International Journal of Development Issues, 13, $155-170$.

25.Syafril. (2005). Ekonomi. Jakarta: PT Bumi Aksara.

26.Warjiyo, P. dan S. (2003). Kebijakan Moneter di Indonesia. Jakarta: Pusat Pendidikan dan Studi Kebanksentralan.

27.Yustika, A. E., Sulistiani, E. H. (2010). Kebijakan Moneter, Sektor Perbankan, dan Peran Badan Supervisi. Jurnal Keuangan dan Perbankan, 14(3), 447-458.

28.Zahonogo, P. (2017). Trade and Economic Growth in Developing Countries: Evidence from SubSaharan Afrieca. Journal of African Trade. 